\title{
Public Infrastructure and Private Production
}

\author{
Glenn Otto and Graham Voss
}

\% n many industrialised countries, levels of public investment have declined significantly during the last three decades. In Australia, the average annual growth rate of general govemment capital declined from 4.1 per cent in the period $1967 / 68-1979 / 80$ to 1.9 per cent in the period 1980/81-1989/90 (Otto \& Voss, 1994a). Concern about this decline surfaced early in the United States (see the references in Ratner, 1983) where some commentators suggested that the decline was in part responsible for the observed slow-down in productivity growth. In order to assess this claim, it is necessary to understand the role of public investment in the economy. Ratner (1983) is an early attempt; but it was the influential work of David Aschauer in the late 1980s that initiated a wide-ranging literature investigating the role of public investment and infrastructure. This literature is now vast and continues to grow.

This article reviews this literature with a particular emphasis on its implications for public policy. We argue that although the literature has proven to be informative in a number of ways, it has not yet provided much of substance to answer the question whether or not the declining levels of public investment are appropriate.

\section{Public Infrastructure}

'Infrastructure' is a broad term for capital projects that are pervasive inputs into production: that is, projects that provide services used at any one time by a large number of different firms and individuals to facilitate production. Examples of infrastructure capital include transportation systems, communications networks, electricity grids, water supply facilities, sewer systems, education systems and basic health-care systems. Each of these provides services to the economy as a whole in a productive capacity. In principle, infrastructure capital may be provided privately or publicly. Traditionally, however, much infrastructure capital has been provided by the public sector.

The standard economic justification for such public provision is that many infrastructure capital projects are public goods. A public good is a commodity with certain features that prevent private decentralised markets from providing it in efficient amounts. The features that define a public good are that it is non-excludable

Glenn Otto and Graham Voss are Lecturers in Economics at the University of New South Wales. 
and/or non-rival. A good is 'non-rival' if consumption by one firm or individual does not preclude consumption by another. The discussion above suggests that, by its very nature, infrastructure consists of capital projects that provide non-rival services. The private sector tends to underprovide non-rival services because private decision-making does not fully reflect the entire benefit of infrastructure projects. A good is 'non-excludable' if by its nature it cannot be withheld from a consumer or producer. A consequence of non-excludability is that private agents are unable to appropriate a competitive return for the commodity and there is no incentive for private provision. If the returns from an infrastructure project are not appropriable, the private sector will not invest in it. This is an inefficient outcome if the services are of productive benefit, and would justify public sector investment. An example would be an urban road where the cost of toll collection is likely to be prohibitively expensive.

A related rationale of public provision of infrastructure capital has to do with external effects. Basic education systems, primary health care, and research and development are commonly thought to have external benefits; that is, benefits to society beyond those accruing to the individuals or firms immediately involved. If these types of benefits exist, then the social returns provide an additional justification for public investment in such projects (universities and hospitals are good examples).

An additional argument for public provision of infrastructure is that certain industries that provide pervasive services throughout the economy exhibit increasing returns to scale. In such circumstances, private provision leads to industrial concentration or, in the extreme, natural monopolies. These market structures, if unregulated, tend to provide too few services at too high a price. The two main means of addressing these problems are regulation and public ownership. Public ownership has been favoured in many instances (for example, the communications industry). Whereas the reasons for this may be largely historical (availability of capital), from an economic perspective public ownership is one of a number of possible means of regulating a particular industry.

Although both public-good and increasing-returns-to-scale arguments have been used to justify public sector investment, there is an important difference between the public provision of infrastructure with a public-good nature and projects with increasing returns to scale. In the former case, the price system fails and the public good must be financed from general revenue. In the latter case, the commodities or services can be priced, in a regulated environment, thus allowing for either public or private ownership of a trading enterprise. In view of this difference, which clearly suggests quite different policy responses, we define public infrastructure as a class of public goods, in particular goods with non-appropriable returns, which are pervasive capital inputs into private production.

\footnotetext{
${ }^{1}$ Notice that public investment can also contribute to social services, quality of life and so forth. Furthermore, in instances such as education, public infrastructure contributes to both private production and general welfare.
} 
In practical terms, establishing what qualifies as public infrastructure is not straightforward, as almost no commodity fully satisfies the strict definition of a public good. Nor are the defining features static. For example, since current technology makes the introduction of tolls on all urban roads prohibitively expensive, urban transportation services are effectively non-excludable. However, future technology may make it quite feasible to record individual road usage and so offer an effective means of pricing urban transportation service. Our view on these matters is essentially pragmatic: public provision of infrastructure projects should be assessed as well as possible on the existing features of the project and whether they prevent private provision of appropriate levels. In addition, public involvement should be reviewed as the economy develops and technologies advance.

The Australian Bureau of Statistics (ABS, Cat. No. 5221) identifies two basic categories of public capital: public enterprise capital and general government capital. Public enterprises are defined as enterprises that price their services and so do not correspond to our definition of public infrastructure. General government capital, which includes (among other things) the stock of roads, dams, tunnels, schools, hospitals and offices, is financed from general revenue and provides services either free or at a nominal cost. This category corresponds more closely to our definition of public infrastructure.

By this definition, public infrastructure capital represents a significant proportion of the total productive capital stock in the Australian economy. In 1991/92 general government capital comprised about 22 per cent of the total stock of productive capital. ${ }^{2}$ The magnitude of this figure provides a powerful reason for identifying and assessing the role of public infrastructure capital; furthermore, it suggests that public infrastructure capital may be an important component of private production.

\section{Policy Issues}

The discussion so far has identified a number of policy issues. The first of these is straightforward and empirical in nature: what is the role of public infrastructure in private production and has this role remained relatively stable? This issue has been addressed by a wide range of studies for a wide collection of countries. Two aspects have received the most attention: a quantitative measure of the role of public capital, and whether public investment crowds out or crowds in private sector investment.

Second, has the recent decline in public investment in Australia been inappropriate? Are we sacrificing future growth by reducing current public infrastructure expenditure? These questions have been only indirectly dealt with in the literature.

Finally, is the current mixture of private and public ownership in Australia desirable, in particular with regard to the public trading enterprises? This issue is not an explicit focus of the public capital literature that we are reviewing in this article.

${ }^{2}$ Public and private housing stocks are excluded from the definition of productive capital. See ABS Cat No. 5221. 
This does not mean we view the issue as unimportant: quite the contrary. It simply reflects that the literature on aggregate public-capital provision does not lead to any immediate conclusions on the subject. So in the following sections, we will consider the results of the literature with regard to the first two policy issues only.

\section{Public Infrastructure and Private Production}

A number of studies have sought to identify the contribution of public infrastructure capital to private production by what can be considered a supply-side approach. In these studies the positive economic effects from an increase in public infrastructure investment are thought to be beneficial primarily because of their alleged effects on private sector productivity; that is, infrastructure capital enhances private sector production. Such supply-side benefits can occur even when the economy is close to or at full employment or capacity. This view of public investment contrasts with the traditional Keynesian aggregate demand effects that are believed to arise from increased government spending, whether current or capital in nature. In the Keynesian model, government spending has a multiplier effect on output when the economy is operating at less than full capacity. But whereas the Keynesian model at best provides a description of the short-run behaviour of the economy, the recent work on infrastructure capital stresses its potential effects on long-run productivity and economic growth.

In effect, what these recent studies attempt to estimate is the private production technology of the aggregate economy with inputs that include some measure of aggregate public infrastructure. These estimated production technologies provide an estimate of the private output elasticity of public infrastructure. For the United States, Aschauer (1989a) reports an elasticity of approximately 0.40 ; a similar result is obtained for Australia by Otto and Voss (1994b). This implies that, holding all else constant, a 1 per cent increase in public capital stock leads to a 0.4 per cent increase in private output.

The most remarkable and controversial feature of these estimates is their magnitude. They imply that, on average, the marginal returns to additional investment in public infrastructure capital are very high, and significantly higher than the returns to additional investment in private capital. This is an unexpected finding and has been used by some economists and policy-makers to justify increasing government expenditure on public infrastructure projects. As long as the returns to public sector investment exceed the returns to private sector investment, private production may potentially be increased by transferring resources from the private sector to the public sector. Another way of putting this is to argue that further public investment is self-financing in the sense that it will lead to an expansion of output in excess of the financing costs of the public investment.

Recent work using more sophisticated econometric techniques provides estimates of the private-output elasticity of public capital that are about half the size of those obtained from Aschauer's methodology (see, for example, Lynde \& Rich- 
mond, 1993; Finn, 1993; Otto \& Voss, 1994b,c). Nevertheless, the estimated elasticities still suggest that increased public investment produces substantial gains.

These results should be treated with some caution. From a statistical viewpoint, it is not clear that the estimated parameters can be interpreted as output elasticities. This is because of the possibility of reverse causality: rather than the estimated relationship being a pure description of the supply side of the aggregate private economy, it is likely to be contaminated by demand-side factors. The basic idea is that instead of being completely exogenous, the stock of public infrastructure capital is likely to respond to factors in the private economy. For example, as the private economy grows, so do tax revenues, which provide a source of financing for additional infrastructure projects. The reverse is true when growth in output or productivity slows. This suggests, not that public infrastructure in not an important component of private production, but rather that it may not be this effect alone that is being captured by aggregate studies.

Relatively few empirical studies address the causality question, and the issue remains largely unresolved. Those studies that do examine causality is a statistical sense have tended to find evidence that causality runs in both directions. An exception is Otto and Voss (1994b), which uses a quarterly data set for the Australian economy and finds evidence suggesting that shocks to private output have virtually no feedback effects on public capital. We interpret this as evidence against the reverse-causality hypothesis. However, more work on this issue is clearly required.

\section{Does Public Investment Crowd Out Private Investment?}

Aschauer (1989b) enquires whether additional public investment spending has a crowding out effect on private investment. An increase in public investment has two potentially offsetting effects. The initial increase in public investment draws resources from the private sector and may lead to an increase in real interest rates; and the extra public investment will tend to substitute for some private investment. This tends initially to depress the level of private investment spending, such that public investment can be said to crowd out private investment spending. But if the stock of public infrastructure capital is an input to private production, then the increase in public capital that arises from the additional public investment may raise the marginal product of private capital, thus eventually providing an incentive for additional private investment. The net long-run effect of an increase in public investment will depend on the relative magnitudes of these two effects.

\footnotetext{
${ }^{3}$ Against this trend are the findings by Holtz-Eakin (1994) for the 48 contiguous states of the United States. When Holtz-Eakin controls for the effects of unobserved, state-specific effects (e.g. land area, location, weather, endowments of natural resources, and so on) he finds no role for public capital in explaining inter-state differences in private sector productivity.

Causality in the statistical sense means that a variable $x$ causes $y$ if $x$ helps to predict future outcomes of $y$.
} 
For the United States, Aschauer finds that an increase in public investment expenditure leads initially to a fall in private investment of an equal magnitude. Subsequently, within three to four years, the marginal productivity of private capital increases and this stimulates additional private investment. The net result on private investment of these two opposing effects is positive, leading Aschauer to conclude that public investment actually crowds in private investment. This mechanism relies on the fact that increases in public infrastructure tend to raise the marginal productivity of private capital. Obviously, if the stock of public capital is excessive, then the additional public infrastructure would have a zero or possibly negative effect on the marginal productivity of private capital.

\section{Limitations of Aggregate Studies}

What are the implications (if any) of these studies for public policy? Is it reasonable to conclude on the basis of such studies alone that increased public investment in infrastructure projects is desirable?

The aggregate or macro-level studies are subject to certain limitations. At best, they tell us something about the average marginal return on the existing stock of public infrastructure. However, the studies are largely silent on the issue of exactly which projects should be allocated scarce government resources. So even if we accept the argument that additional public spending on infrastructure is required, the aggregate studies do not provide any guidance as to the magnitude or direction of any additional expenditure.

One response to this difficulty is to apply benefit-cost analysis to individual infrastructure projects: those with the highest benefit-cost ratios slould be undertaken. The problem here is that the rates of return implied by the aggregate studies tend to be at least an order of magnitude larger than benefit estimates obtained for individual public projects from benefit-cost studies. In other words, benefit-cost studies may be systematically underestimating the returns to public infrastructure projects.

Why are the benefit-cost studies performing in this unsatisfactory manner? One simple answer is that the results from the aggregate studies are biased upwards and hence unreliable. However, Aschauer (1993) and others argue that the problem lies with the benefit-cost studies. Because of their local and project-based nature, they are allegedly unable to measure completely the indirect benefits of public infrastructure projects: which benefits are, however, measured by the macro-based aggregate studies. This argument is indirectly supported by the observation that the estimated contribution of public capital to private production tends to increase with the level of aggregation of the data: that is, the smallest effects are obtained by studies that use city or local data, while the largest effects are obtained from national data. But this still leaves us with little information on the specific nature of the 
complete effects of particular infrastructure projects. What is required is a better understanding of the specific roles of public infrastructure.

\section{What Have We Learned?}

In view of these caveats, what do these existing studies tell us? In our view, what the existing studies (should) do is to make policy-makers aware of the historical contribution made by public infrastructure capital to private production and to suggest that sudden large reductions in public investment may have important consequences for future economic growth. Thus, reducing public investment purely as a means of cutting back the size of the government sector or the budget deficit is unlikely to be an optimal policy from a longer-term perspective (see Alesina, Gruen \& Jones, 1991).

This is not to imply that the level of public investment in infrastructure capital should never fall, or even that the declines observed in Australia during the second half of the 1980s were unwarranted. A number of reasonable explanations for this decline are available. Perhaps the existing stock of public infrastructure capital was excessive (but this tends not to show up in most empirical studies). Perhaps the existing stock of public infrastructure capital is being used more efficiently. Implicit in virtually all of the empirical studies is the assumption that the measured stock of infrastructure capital (in constant prices) is an adequate proxy for the more theoretically relevant flow of services that individuals and firms actually obtain from infrastructure capital. Thus, if existing infrastructure capital were utilised more efficiently, due for example to the use of more appropriate pricing for infrastructure services, then we might observe a decline in the public investment to output ratio without any implications for future growth. The existing studies do not provide a satisfactory resolution to these issues. The empirical studies that assess the role of public infrastructure are primarily concerned with establishing whether or not a role exists. Very few attempts have been made to discover whether actually existing levels of public infrastructure are at or close to their efficient levels.

It is often argued that efficiency requires the marginal returns to public and private capital (and presumably human capital as well) to be equal: to the extent that the marginal return to public infrastructure capital exceeds that of private and human capital, additional public investment should be undertaken to equalise returns. For this argument to be valid, a number of restrictive assumptions are needed. First of all, resource costs involved in financing both public and private investment projects must be roughly equal. However, public infrastructure must be financed from general taxation, which may have distortionary effects on the private economy. For example, income taxes have a disincentive effect on labour provision, lowering private-sector output and productivity.

\footnotetext{
5 One source of this better understanding may come from recent work on the 'new growth theory' that has indicated that private capital spillover extenialities are a possible cause of economic growth (see Romer, 1986, and Dowrick, 1994). The question arises as to whether a similar analysis can be applied to public capital.
} 
Additional complications arise if uncertainty is introduced into the analysis. Then real returns to investing in different assets are typically not equalised; rather, the differential rates of return reflect the different risk components of different assets. So high returns to public infrastructure may be a reflection of the relative riskiness of these projects, due to their long payoff horizons, for example.

Finally, the comparison of estimated returns is not strictly correct from a statistical perspective. A correct test of whether or not the returns to different assets are equal requires estimating the returns under the hypothesis of efficiency and testing whether the equality condition is satisfied statistically. The studies considered above compare the unrestricted estimates only informally. Preliminary evidence in Otto and Voss (1994c) suggests that this can have a substantial influence on the conclusion regarding the appropriate level of public infrastructure.

\section{Conclusions}

A potential role for the public sector in a mixed economy is the provision of public infrastructure. We define public infrastructure as a pervasive capital input to private production that has, to some extent, non-appropriable returns. By its nature, public infrastructure services are not marketable, and public investment is generally warranted. These features of public infrastructure contrast with public investment in trading enterprises; in this latter case, returns are generally appropriable, and the case for public involvement is weaker. Considerable effort has focused on the productive role of public investment; in general, the focus is on public infrastructure, although this distinction is not always clear. These efforts have identified a significant role for public infrastructure in private production. Unfortunately, these results have as yet provided little guidance for public policy. Public sector decisions are not made at the aggregate level (on which these studies focus) but at a project level. Beyond the general conclusion that there may exist additional benefits beyond standard cost-benefit studies, these aggregate studies provide no direct quantifrable information to assist project evaluation. In our opinion, new research efforts should not address aggregate provision but should be directed towards a more complete understanding of the relationship between infrastructure and private production at an industry level. 


\section{References}

Alesina, A., D. Gruen \& M. Jones (1991), 'Fiscal Imbalance, the Real Exchange Rate and Australia's External Balance', The Australian Economic Review, 3rd quarter: 38-51.

Aschauer, D. (1989a), 'Is Public Expenditure Productive?', Journal of Monetary Economics 23: 177200.

(1989b), 'Does Public Capital Crowd Out Private Capital', Joumal of Monetary Economics 24: 171-88.

(1993), 'Public Capital, Productivity and Macroeconomic Performance: A Literature Review', Report prepared for Apogee Research Inc. for the US Army Corp of Engineers, mimeo, Bates College.

Dowrick, S. (1994), 'Fiscal Policy and Investment: the New Supply Side Economics', Centre for Fconomic Policy Research, Australian National University, Canberra (Discussion Paper No. 311).

Finn, M. (1993), 'Is All Government Capital Productive', Economic Quarterly 79: 53-80.

Holtz-Eakin, D. (1994), 'Public-Sector Capital and the Productivity Puzzle', Review of Economics and Statistics 76: 12-21.

Lynde, C. \& J. Richmond (1993), 'Public Capital and Total Factor Productivity', International Economic Review 34: 401-14.

Otto, G. \& G. Voss (1994a), 'Public Capital and Private Sector Productivity', Economic Record 70: $121-32$.

- (1994b), 'Long and Short Run Interactions of Public Capital, Private Output, Capital and Hours', University of New South Wales Discussion Paper 94/3.

- (1994c), 'A Test of Public Capital Efficiency', mimeo, University of New South Wales.

Ratner, J. (1983), 'Government Capital and the Production Function for US Private Output', Economic Letters 13: 213-17.

Romer, P. (1986), 'Increasing Returns and Long-Run Growth', Journal of Political Economy 99: 50021.

Research funding from the Australia Research Council is gratefully acknowledged, as are the suggestions of the referees. 